\title{
INFLUENCE OF SOME INHIBITING AND ACTIVATING SUBSTANCES ON THE LIGHT REACTION IN VITRO OF PHOTOBACTERIUM PHOSPHOREUM
}

\author{
WILLEMKE TERPSTRA AND C. L. M. STEENBERGEN \\ Biophysical Research Group, Physical Institute, State University, Utrecht (The Netherlands)
}

(Received February I 2 th, 1964)

\section{SUMMARY}

Addition of $\mathrm{H}_{2} \mathrm{O}_{2}$ to a bacterial luciferase preparation resulted in the formation of a compound with a fluorescence maximum at about $470 \mathrm{~m} \mu$. This compound was probably the same as the one that is formed as a result of ultraviolet irradiation of luciferase preparations after addition of $\mathrm{FMNH}_{2}$. It is assumed to be the luminescent molecule in bacterial luminescence.

The effect of a number of substances $\left(\mathrm{K}_{3} \mathrm{Fe}(\mathrm{CN})_{6}, \mathrm{~K}_{4} \mathrm{Fe}(\mathrm{CN})_{6}\right.$, ascorbic acid, peroxidase (donor: $\mathrm{H}_{2} \mathrm{O}_{2}$ oxidoreductase, EC I.II.I.7), tryptophan and $p$-chloromercuribenzoate) on both the light reaction and the fluorescence increase reaction was investigated. Substances inhibiting the fluorescence increase reaction $\left(\mathrm{K}_{3} \mathrm{Fe}(\mathrm{CN})_{6}\right.$, $\mathrm{K}_{4} \mathrm{Fe}(\mathrm{CN})_{6}$, ascorbic acid) likewise could inhibit the light reaction. Both effects are, at least partly, ascribed to an effect on the fluorescent group of luciferase. Light reaction inhibitors affecting other groups at the enzyme surface ( $p$-chloromercuribenzoate) did not influence the fluorescence increase effect. Activators of the light reaction (cysteine, $\mathrm{K}_{4} \mathrm{Fe}(\mathrm{CN})_{6}$ ) are suggested to act by their protective action on sulfhydryl groups or on dissociable groups, presumed to be attached to these sulfhydryl groups.

A discussion of the results leads to the conclusion that the light reaction consists of at least two consecutive reactions, involving two different groups of the luciferase molecule.

\section{INTRODUCTION}

In a previous paper ${ }^{1}$ we reported that addition of $\mathrm{FMNH}_{2}$ to a bacterial enzyme preparation results in the formation of some compound which is transformed by irradiation with ultraviolet light $(366 \mathrm{~m} \mu)$ into a fluorescent substance with a fluorescence maximum around $470 \mathrm{~m} \mu$. The compound was suggested to be a precursor of the light-emitting molecule in bacterial luminescence. In the light of experiments of TETher And TURnbulL ${ }^{2}$ the conversion of the precursor to the fluorescent substance was tentatively ascribed to an oxidation reaction. The aim of the present experiments was to find out whether (a) the formation of the fluorescent substance is indeed an oxidation reaction and (b) any correlation can be found between the formation of 
this compound and the light reaction. To this end the influence of some oxidizing and reducing substances on both the fluorescence increase reaction and the light reaction was investigated. The results, combined with both those of other authors and those of our earlier investigations were used to set up a reaction scheme for bacterial bioluminescence.

\section{MATERIAL AND METHODS}

These were essentially the same as described in a preceding paper ${ }^{1}$. The composition of reaction mixtures is indicated in the legends to tables and figures.

\section{The light reaction}

\section{RESULTS}

Infuence of $\mathrm{K}_{\mathbf{3}} \mathrm{Fe}(\mathrm{CN})_{6} \cdot \mathrm{K}_{3} \mathrm{Fe}(\mathrm{CN})_{6}$ is known to be an inhibitor of the light reaction ${ }^{3,4}$, the inhibition is ascribed to the oxidation of $\mathrm{FMNH}_{2}$ outside the light reaction. The results of our experiments, using $\mathrm{FMNH}_{2}$ to evoke the light reaction, were in accordance with this explanation: inhibition occurred if the amount of $\mathrm{K}_{3} \mathrm{Fe}(\mathrm{CN})_{6}$ was such as to render the remaining amount of $\mathrm{FMNH}_{2}$ limiting for the light reaction. Addition of more $\mathrm{FMNH}_{2}$ could counteract the inhibiting effect of $\mathrm{K}_{3} \mathrm{Fe}(\mathrm{CN})_{6}$. In experiments using $\mathrm{NADH}_{2}$ and $\mathrm{FMN}$ for evoking the light reaction, the influence of $\mathrm{K}_{3} \mathrm{Fe}(\mathrm{CN})_{6}$ became less clear: in the first moments the reaction was completely or considerably inhibited; after that the reaction rate rose, but did not reach the level of the control (Fig. I). It was established that $\mathrm{K}_{\mathbf{3}} \mathrm{Fe}(\mathrm{CN})_{6}$ did not inhibit $\mathrm{NADH}_{2}$ oxidase. The "lag-phase" in the light-reaction level, which has also been described by MCELROY AND GREEN 4 can be explained by assuming that, in the first minutes, $\mathrm{K}_{3} \mathrm{Fe}(\mathrm{CN})_{6}$ is reduced by the $\mathrm{NADH}_{2}-\mathrm{FMN}$ system, after which the remaining $\mathrm{NADH}_{2}$ is used in the light reaction. The relatively low light reaction in the second phase, as compared to the control, may be explained after considering the next section.

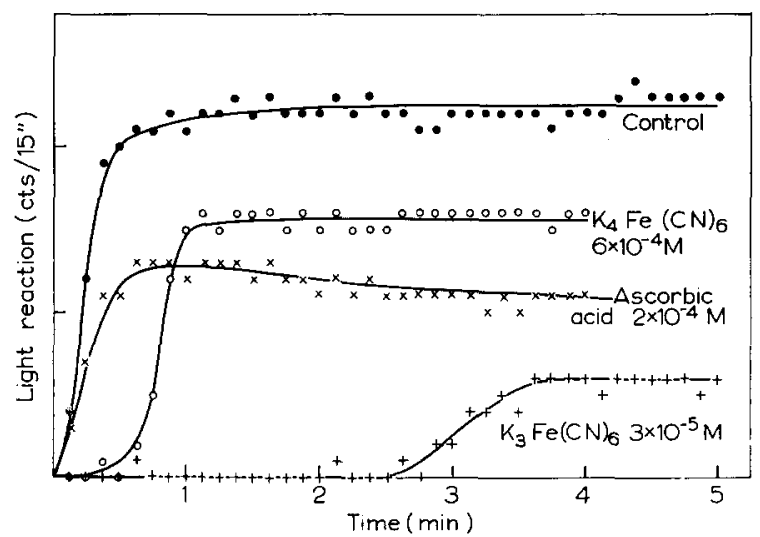

Fig. I. Influence of $\mathrm{K}_{3} \mathrm{Fe}(\mathrm{CN})_{6}, \mathrm{~K}_{4} \mathrm{Fe}(\mathrm{CN})_{6}$ and ascorbic acid on the light reaction evoked by addition of $\mathrm{NADH}_{2}$ and FMN. Reaction mixtures: I.4 $\mathrm{ml} \mathrm{o.I} \mathrm{M} \mathrm{phosphate} \mathrm{buffer} \mathrm{(} \mathrm{pH} 7.0$ ); $0.5 \mathrm{ml}$ bacterial lysate; $0.03 \mathrm{ml}$ aqueous FMN solution, final FMN concentration I.5. $\mathbf{I}^{-\mathbf{5}} \mathrm{M} ; 0 . \mathrm{l} \mathrm{ml}$ phosphate buffer or $\mathrm{K}_{3} \mathrm{Fe}(\mathrm{CN})_{6}, \mathrm{~K}_{4} \mathrm{Fe}(\mathrm{CN})_{6}$ or ascorbic acid in phosphate buffer, final concentrations as indicated; $0.03 \mathrm{ml}$ palmital, saturated solution in methanol. At zero time $0.5 \mathrm{ml} \mathrm{NADH}_{2}$ solution in buffer, containing $0.25 \mathrm{mg} \mathrm{NADH} \mathrm{Na}_{2}$ was added. 
Influence of $\mathrm{K}_{4} \mathrm{Fe}(\mathrm{CN})_{6}$. Considering the light reaction as far as it is known at present, there was no reason to expect any influence of $\mathrm{K}_{4} \mathrm{Fe}(\mathrm{CN})_{\mathbf{6}}$. However, a clear effect of $\mathrm{K}_{4} \mathrm{Fe}(\mathrm{CN})_{6}$ was measured. Fig. I shows the effect of $\mathrm{K}_{4} \mathrm{Fe}(\mathrm{CN})_{6}$ on the light reaction evoked by addition of $\mathrm{NADH}_{2}$ and $\mathrm{FMN}$ : there was a distinct inhibiting action. Besides, the beginning of the curve of light reaction versus time is S-shaped. $\mathrm{K}_{4} \mathrm{Fe}(\mathrm{CN})_{6}$ did not influence $\mathrm{NADH}_{2}$-oxidase activity.

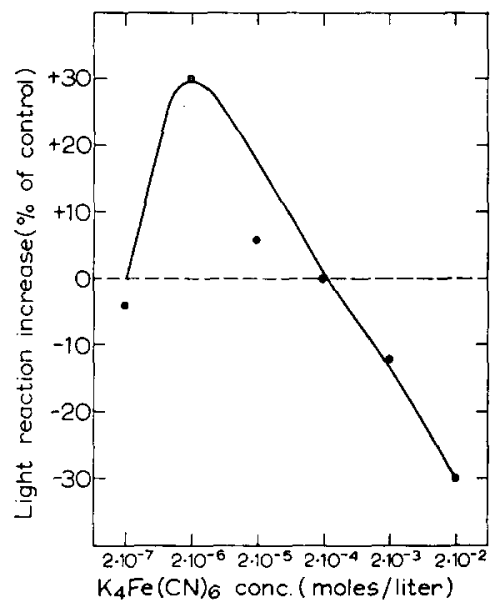

Fig. 2. Influence of $\mathrm{K}_{4} \mathrm{Fe}(\mathrm{CN})_{6}$ concentration on its effect on the light reaction. Reaction mixtures: $0.005 \mathrm{ml}$ luciferase preparation (HCl-precipitate); $1.9 \mathrm{ml}$ o.I M phosphate buffer (pH 7.0); $0.1 \mathrm{ml}$ water or aqueous $\mathrm{K}_{4} \mathrm{Fe}(\mathrm{CN})_{6}$ solution, final concentration as indicated; $0.02 \mathrm{ml}$ palmital, saturated solution in methanol. The reaction was initiated by adding $0.5 \mathrm{ml}$ aqueous $\mathrm{FMNH}_{2}$ solution, final FMN concentration $\mathrm{IO}^{-5} \mathrm{M}$.

In the light reaction evoked by addition of $\mathrm{FMNH}_{2}$ to the luciferase preparation, $\mathrm{K}_{4} \mathrm{Fe}(\mathrm{CN})_{6}$ could act as an inhibitor or as an activator. What happened depended on both enzyme and $\mathrm{FMNH}_{2}$ concentration: increasing the enzyme concentration or decreasing $\mathrm{FMNH}_{2}$ concentration tended to increase the inhibiting effect of $\mathrm{K}_{4} \mathrm{Fe}(\mathrm{CN})_{6}$. Low enzyme concentration and high $\mathrm{FMNH}_{2}$ concentration favoured the activating effect of $\mathrm{K}_{4} \mathrm{Fe}(\mathrm{CN})_{6}$. The amount of palmital added had no influence on the effect of $\mathrm{K}_{4} \mathrm{Fe}(\mathrm{CN})_{6}$. Under a favourable ratio of enzyme to $\mathrm{FMNH}_{2}$ concentration, $\mathrm{K}_{4} \mathrm{Fe}(\mathrm{CN})_{6}$ could show an inhibiting action in high concentrations and an activating effect in lower concentrations (Fig. 2). Tables I and II detail some experiments on the influence of $\mathrm{FMNH}_{2}$ and enzyme concentrations on the effect of $\mathrm{K}_{4} \mathrm{Fe}(\mathrm{CN})_{6}$ on the light reaction.

The activating effect of $\mathrm{K}_{4} \mathrm{Fe}(\mathrm{CN})_{6}$ was not perceptible in the presence of cysteine. Cysteine itself strongly activated luciferase in diluted solution ( $c f$. RILEY ${ }^{5}$ ).

Influence of ascorbic acid. Ascorbic acid inhibited the light reaction evoked by addition of $\mathrm{NADH}_{2}$ and FMN to a luciferase preparation (Fig. I). In the light reaction initiated by $\mathrm{FMNH}_{2}$, also, a clear inhibition was measured in the presence of ascorbic acid $\left(0.5 \cdot 1 \mathrm{O}^{-4}-4 \cdot \mathrm{IO}^{-4} \mathrm{M}\right)$. There was no significant difference between the action of ascorbic acid (fresh solution in phosphate buffer) and that of oxidized ascorbic acid (6-48-h-old solutions, showing a decreased or zero reducing activity). Increasing the $\mathrm{FMNH}_{2}$ concentration resulted in a relatively slight decrease of the inhibiting effect. Increase of the enzyme concentration decreased the percentual inhibition by ascorbic 
TABLE I

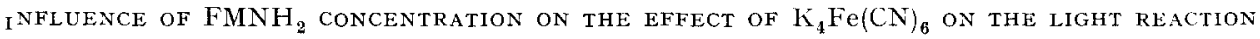

Reaction mixtures: luciferase preparation (HCl-precipitate): $0.005,0.02$ and $0.008 \mathrm{ml}$ in Expts. I, 2 and 3, respectively; $\mathrm{K}_{4} \mathrm{Fe}(\mathrm{CN})_{6}: 10^{-4} \mathrm{M}$ (Expt. $\mathrm{I}$ ) or $2 \cdot 10^{-4} \mathrm{M}$ (Expts. 2 and 3); palmital: saturated solution in methanol, $0.02 \mathrm{ml}$; o. I $\mathrm{M}$ phosphate buffer $(\mathrm{pH} 7.0)$ until a final volume of $2.0 \mathrm{ml}$. The reaction was initiated by adding $0.5 \mathrm{ml}$ aqueous $\mathrm{FMNH}_{2}$ solution. Final FMN concentrations: low concentration : $4^{\cdot 10^{-6}} \mathrm{M}$ (Expt. 1) or $2.5^{\circ} 10^{-6} \mathrm{M}$ (Expts. 2 and 3 ), high concentration: $4 \cdot 10^{-5} \mathrm{M}$ (Expt. I) or $2.5 \cdot 10^{-5} \mathrm{M}$ (Expts. 2 and 3 ). Experiments were made with different cnzyme preparations and cannot be compared mutually.

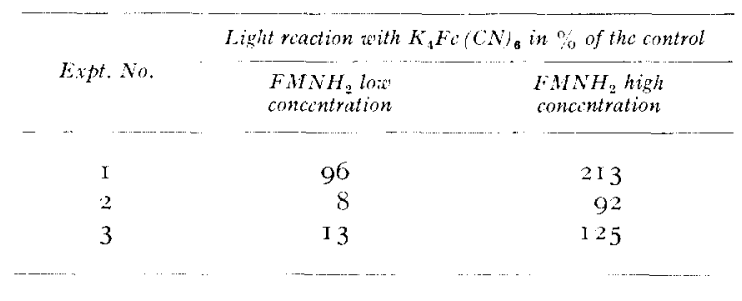

TABLE II

INFLUENCE OF LUCIFERASE CONCENTRATION ON THE EFFECT OF $\mathrm{K}_{4} \mathrm{Fe}(\mathrm{CN})_{6}$ ON THE LIGHT REACTION

IReaction mixtures: luciferase preparation ( $\mathrm{HCl}$-precipitate) : $0.025 \mathrm{ml}$ (low concn.) and $0.125 \mathrm{ml}$ (high conen.) (Expt. I); $0.006 \mathrm{ml}$ (low concn.) and $0.03 \mathrm{ml}$ (high concn.) (Expt. 2); $0.01 \mathrm{ml}$ (low concn.) and $0.05 \mathrm{ml}$ (high concn.) (Expt. 3); $\mathrm{K}_{4} \mathrm{Fe}(\mathrm{CN})_{6}: 2 \cdot 1 \mathrm{O}^{-4} \mathrm{M}, 1 \mathrm{O}^{-2} \mathrm{M}$ and $2.5 \cdot \mathrm{I} \mathrm{O}^{-5} \mathrm{M}$ in Expts. 1, 2 and 3, respectively; palmital: saturated solution in methanol, $0.02 \mathrm{ml}$; $0.1 \mathrm{M}$ phosphate buffer $(\mathrm{pH} 7.0)$ until a final volume of $2.3 \mathrm{ml}$. The reaction was initiated by adding $0.2 \mathrm{ml}$ aqueous $\mathrm{FMNH}_{2}$ solution. Final FMN concentration $10^{-5} \mathrm{M}$ (Expt. 1) or $2.5 \cdot 10^{-5} \mathrm{M}$ (Expts. 2 and 3). Experiments were made with different enzyme preparations and cannot be compared mutually.

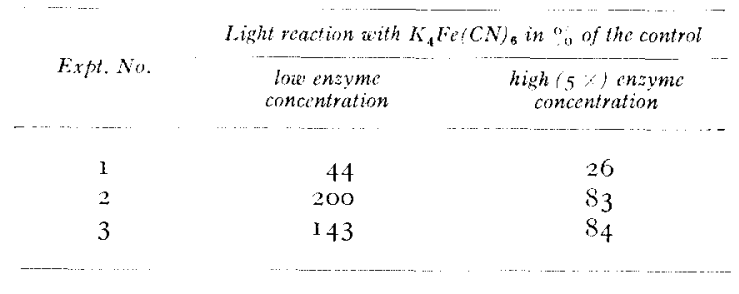

TABLE III

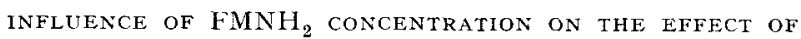
ASCORBIC ACID ON THE LIGHT REACTION

Reaction mixtures: luciferase preparation ( $\mathrm{HCl}$-precipitate) : $0.035,0.02$ and $0.008 \mathrm{ml}$ in Expts. I, 2 and 3, respectively; ascorbic acid: $4 \cdot \mathrm{I}^{-4} \mathrm{M}$ (Expt. I) or $2 \cdot 1 \mathrm{O}^{-4} \mathrm{M}$ (Expts. 2 and 3 ); palmital: saturated solution in methanol, $0.02 \mathrm{ml}$; $0.1 \mathrm{M}$ phosphate buffer ( $\mathrm{pH} 7.0$ ) until a final volume of $2.0 \mathrm{ml}$. The reaction was initiated by adding $0.5 \mathrm{ml}$ aqueous FMN $_{2}$ solution. Final FMN concentrations: low concentration : $10^{-5} \mathrm{M}$ (Expt. I) or $2.5^{-} \mathrm{IO}^{-6} \mathrm{M}$ (Expts. 2 and 3 ), high concentration: $10^{-4} \mathrm{M}$ (Expt. I) or $2.5 \cdot \mathrm{IO}^{-5} \mathrm{M}$ (Expts. 2 and 3 ). Experiments were made with different enzyme preparations and cannot be compared mutually.

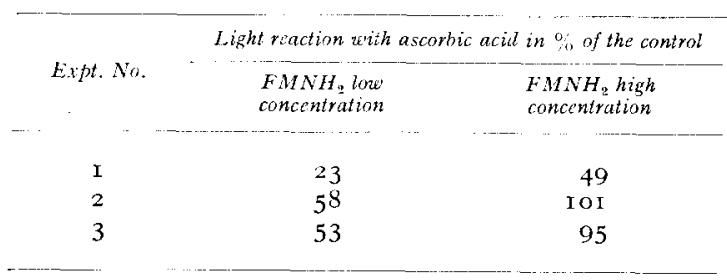


TABLE IV

INFLUENCE OF LUCIFERASE CONCENTRATION ON THE EFFECT OF ASCORBIC ACID ON THE LIGHT REACTION

Reaction mixtures: luciferase preparation (HCl-precipitate): low concentration : o.or ml (Expts, $I$ and 3) or $0.005 \mathrm{ml}$ (Expt 2); high concentration: $0.05 \mathrm{ml}$ (Expts. I and 3) or $0.025 \mathrm{ml}$ (Expt. 2); ascorbic acid: $2 \cdot 10^{-4} \mathrm{M}$ (Expts. I and 3) or $\mathrm{IO}^{-4} \mathrm{M}$ (Expt. 2); palmital: saturated solution in methanol, $0.02 \mathrm{ml}$; o.I $\mathrm{M}$ phosphate buffer $(\mathrm{pH} 7.0)$ until a final volume of $2.3 \mathrm{ml}$. The reaction was initiated by adding $0.2 \mathrm{ml}$ aqueous $\mathrm{FMNH}_{2}$ solution. Final FMN concentration $\mathrm{IO}^{-5} \mathrm{M}^{-5}$ (Expt. I) or $2.5^{\circ} \mathrm{I}^{-5} \mathrm{M}$ (Expts. 2 and 3 ). Experiments were made with different enzyme preparations and cannot be compared mutually.

\begin{tabular}{ccc}
\hline Expt. No. & $\begin{array}{c}\text { Light veaction with ascorbic acid in }{ }_{0}^{\circ} \text { of the control } \\
\text { lowe inzyme } \\
\text { concontration }\end{array}$ & $\begin{array}{c}\text { high }(5 \times) \text { ensyme } \\
\text { concentration }\end{array}$ \\
\hline I & 50 & 87 \\
2 & 26 & 90 \\
3 & 70 & 100 \\
\hline
\end{tabular}

acid. The palmital concentration did not significantly influence its effect. Tables III and IV detail some experiments on the influence of $\mathrm{FMNH}_{2}$ and enzyme concentrations on the effect of ascorbic acid on the light reaction.

Infuence of tryptophan. Tryptophan was investigated because it had a marked effect in the fluorescence experiments. In the light reaction no influence of tryptophan in a concentration as high as $2 \mathrm{mM}$ could be found.

Infuence of peroxidase. Addition of peroxidase (donor: $\mathrm{H}_{2} \mathrm{O}_{2}$ oxidoreductase, EC I.I I.I.7) (Boehringer, from horse radish) inhibited the light reaction initiated by addition of $\mathrm{FMNH}_{2}$ to a luciferase preparation: o. $\mathrm{Img}$ peroxidase in $3.0 \mathrm{ml}$ reaction mixture resulted in about $80 \%$ inhibition of the light reaction.

\section{The fluorescence increase reaction}

Infuence of $\mathrm{K}_{3} \mathrm{Fe}(\mathrm{CN})_{6}, \mathrm{~K}_{4} \mathrm{Fe}(\mathrm{CN})_{6}$, ascorbic acid and $\mathrm{H}_{2} \mathrm{O}_{2}$. In previous experiments ${ }^{1}$ it was found that a substance with a fluorescence maximum at about $470 \mathrm{~m} \mu$ is formed after addition of $\mathrm{FMNH}_{2}$ to a luciferase preparation and subsequent irradiation with ultraviolet light. In the following account this reaction will be called the "fluorescence increase reaction". In order to find an indication whether the formation of the fluorescent compound was due to an oxidation or reduction reaction the influence of oxidizing and reducing substances on the fluorescence increase effect was investigated. In the presence of $\mathrm{K}_{3} \mathrm{Fe}(\mathrm{CN})_{6}$, as well as of $\mathrm{K}_{4} \mathrm{Fe}(\mathrm{CN})_{6}$ and ascorbic acid, the fluorescence increase effect did not show up (Fig. 3 a-d). Addition of $\mathrm{H}_{2} \mathrm{O}_{2}$ to the reaction mixture resulted in an increase of the fluorescence, measured at $470 \mathrm{~m} \mu$, but the typical form of the time course of the fluorescence increase effect had disappeared. $\mathrm{H}_{2} \mathrm{O}_{2}$ addition increased the $470-\mathrm{m} \mu$ fluorescence independently of the presence of $\mathrm{FMNH}_{2}$ or FMN (Fig. 4). Therefore, the observed increase of the fluorescence at $470 \mathrm{~m} \mu$ is assumed to be due to an oxidation product of some substance in the luciferase preparation. In order to locate the fluorescence maximum of the substance formed, a fluorescence difference spectrum was established by substracting the original spectrum of the enzyme preparation from the spectrum obtained upon addition of $\mathrm{H}_{2} \mathrm{O}_{2}$. The resulting spectrum (Fig. 5) showed a maximum at about $470 \mathrm{~m} \mu$. 
Fig. 3. Influence of $\mathrm{K}_{3} \mathrm{Fe}(\mathrm{CN})_{6}, \mathrm{~K}_{4} \mathrm{Fe}(\mathrm{CN})_{6}$ and ascorbic acid on the fluorescence increase effect, caused by bacterial luciferase preparations $(a, b, c, d)$. The fluorescence increase effect caused by tryptophan (c). Reaction mixtures: o. $\mathrm{ml}$ luciferase preparation (HCl-precipitate) (a, b, c, d), tryptophan solution in o.t M phosphate buffer $(\mathrm{pH} 7.0)$, final concentration $2 \cdot 1 \mathrm{O}^{-5} \mathrm{M}(\mathrm{e})$, or buffer (f). $2.4 \mathrm{ml}$ o. I M phosphate buffer $(\mathrm{pH} 7.0)$, containing $\mathrm{K}_{3} \mathrm{Fe}(\mathrm{CN})_{6}(\mathrm{~b}), \mathrm{K}_{1} \mathrm{Fe}-$ $(\mathrm{CN})_{6}(\mathrm{c})$ or ascorbic acid (d) as indicated; $0.5 \mathrm{ml}$ aqueous $\mathrm{FMNH}_{2}$ solution, final FMN concentration $2.5 \cdot 10^{-5} \mathrm{M}$, added as indicated.

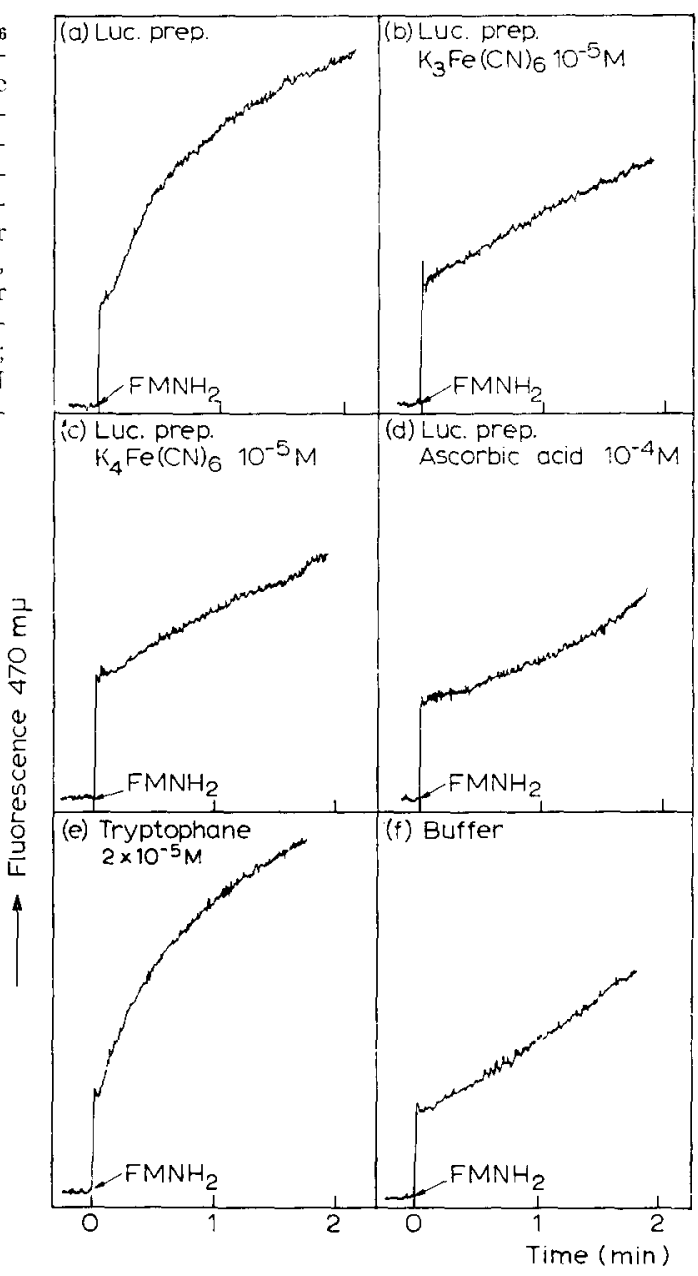

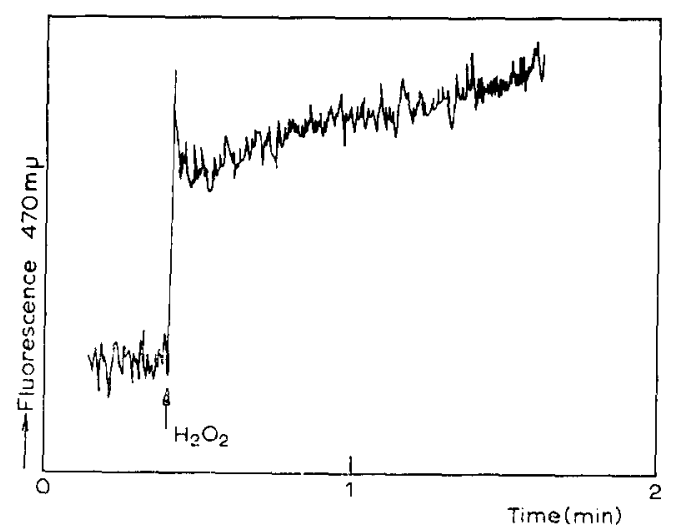

Fig. 4. Effect of $\mathrm{H}_{2} \mathrm{O}_{2}$ on fluorescence at $470 \mathrm{~m} \mu$ of bacterial luciferase preparations. Reaction mixture: $2.5 \mathrm{ml}$ o.I $\mathrm{M}$ phosphate buffer ( $\mathrm{pH} 7.0$ ); $0.2 \mathrm{ml}$ luciferase preparation (HCl-precipitate); $0.3 \mathrm{ml} \mathrm{H}_{2} \mathrm{O}_{2} 30 \%$. 
The $\mathrm{H}_{2} \mathrm{O}_{2}$-induced increase of fluorescence at $470 \mathrm{~m} \mu$ could not be observed on addition of $\mathrm{H}_{2} \mathrm{O}_{2}$ to solution $\mathrm{U}$. It is reminded that "solution U" is called the neutralized supernatant of a $\mathrm{HCl}$-precipitate of bacterial lysate; it increases the light reaction of diluted enzyme preparations ${ }^{\mathbf{1}, \mathbf{6}}$. Solution $U$ did not show a fluorescence increase effect on addition of $\mathrm{FMNH}_{2}$, either.

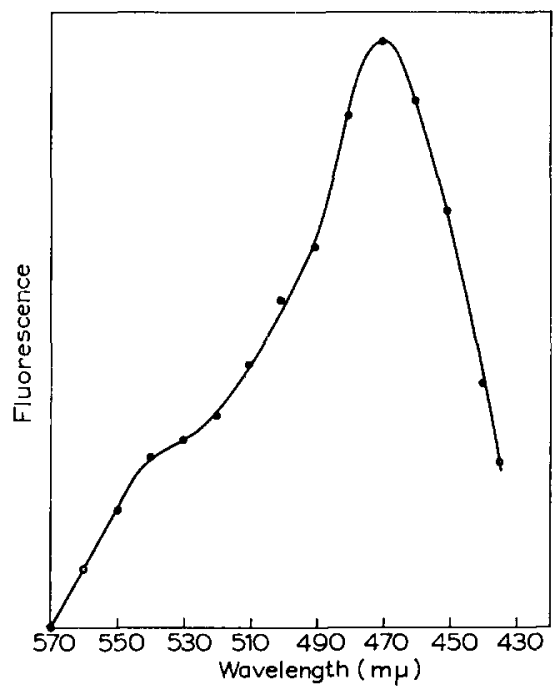

Fig. 5. Fluorescence spectrum of the compound formed on addition of $\mathrm{H}_{2} \mathrm{O}_{2}$ to a bacterial luciferase preparation. The spectrum is obtained by substracting the spectrum of luciferase solution plus $\mathrm{H}_{2} \mathrm{O}$ from that of luciferase solution plus $\mathrm{H}_{2} \mathrm{O}_{2}$, both after 10 min in the dark. Reaction mixture: $2.7 \mathrm{ml}$ o.I M phosphate buffer ( $\mathrm{pH}$ 7.0); $0.1 \mathrm{ml}$ luciferase preparation ( $\mathrm{HCl}$-precipitate); $0.2 \mathrm{ml} \mathrm{H}_{2} \mathrm{O}$ and $\mathrm{H}_{2} \mathrm{O}_{2} 30 \%$, respectively.

As the fluorescence spectrum of the substance formed on addition of $\mathrm{H}_{2} \mathrm{O}_{2}$ to the luciferase preparation is about the same as that of the substance formed in the fluorescence increase effect ${ }^{1}$, the possibility was investigated that the formation of the latter substance might be due to the action of $\mathrm{H}_{2} \mathrm{O}_{2}$ evolved on oxidation of added $\mathrm{FMNH}_{2}$. We therefore studied the influence of $\mathrm{H}_{2} \mathrm{O}_{2}$ in a concentration approximating that which might be expected to result from the added amount of $\mathrm{FMNH}_{2}$. No effect could be found.

Infuence of tryptophan. IsENBERG et al. ${ }^{7,8}$ described the formation of chargetransfer complexes between riboflavin or FMN and tryptophan. In this connection we examined whether the fluorescence increase effect might be due to the formation of a charge-transfer complex between luciferase and $\mathrm{FMNH}_{2}$. Addition of $\mathrm{FMNH}_{2}$ to a tryptophan solution resulted in a fluorescence increase effect on irradiation with ultraviolet light. The shape of the curve resembles the one obtained with a luciferase preparation instead of with tryptophan (Fig. $3 \mathrm{e}$ ).

If FMN was added instead of $\mathrm{FMNH}_{2}$, the fluorescence of the mixture tended to increase less on ultraviolet irradiation than without tryptophan. This effect was not found with luciferase preparations.

Addition of $\mathrm{H}_{2} \mathrm{O}_{2}$ to a solution of tryptophan did not result in an increased fluorescence at $470 \mathrm{~m} \mu$.

Infuence of $p$-chloromercuribenzoate and peroxidase. p-Chloromercuribenzoate, a 
well-known inhibitor of the light reaction ${ }^{3,9}$ did not show a measurable influence on the fluorescence increase effect. The concentration tested was $5^{\cdot} \mathrm{IO}^{-4} \mathrm{M}$. The same appeared to be true for peroxidase ( $\mathrm{Img}$ per $3 \mathrm{ml}$ reaction mixture).

\section{DISCUSSION}

An attempt can be made to design a reaction scheme for bioluminescence of bacteria which fits in with the results obtained in the experiments described, together with those of former experiments and with those of other investigators.

Addition of $\mathrm{H}_{2} \mathrm{O}_{2}$ to a luciferase preparation results in the formation of a substance with a fluorescence maximum at about $470 \mathrm{~m} \mu$. Because of the location of this maximum we assume that this compound is the same as the one formed on ultraviolet irradiation after addition of $\mathrm{FMNH}_{2}$ (the fluorescence increase reaction), and that this substance is the light-emitting molecule in bacterial bioluminescence. In the fluorescence increase reaction FMN is supposed to be the ultimate electron acceptor, while in bioluminescence its place is taken by $\mathrm{O}_{2}$. Light emission occurs, therefore, by the oxidized form of some compound present in the luciferase preparation. This compound is associated with the protein of the enzyme preparation, since solution $U$, which is assumed to contain a non-protein substance dissociated from the active luciferase ${ }^{6}$, does not show the fluorescence increase effect. Besides, addition of $\mathrm{H}_{2} \mathrm{O}_{2}$ to solution $\mathrm{U}$ does not result in fluorescence increase at $470 \mathrm{~m} \mu$.

As no increased fluorescence is found in a light-reaction mixture at the end of the light reaction ${ }^{1}$, the light-emitting molecule should be in the oxidized form only during the light reaction. As there is no decreased capacity for a light reaction upon a second addition of $\mathrm{FMNH}_{2}$ or $\mathrm{NADH}_{2}$ (ref. Io), the originally reduced, non-fluorescent, form of the light-emitting molecule should be reformed during the light reaction. The sole source of electrons is $\mathrm{FMNH}_{2}$ or some substance reduced by $\mathrm{FMNH}_{2}$. It is improbable that the re-reduction takes place by means of sulfhydryl groups, formed on addition of $\mathrm{FMNH}_{2}$ for if such were the case, it is not clear why an enzyme containing oxidized sulfhydryl groups would be inactive on addition of $\mathrm{FMNH}_{2}$. It may be recalled here that RILEY ${ }^{5}$ ascribes inactivation of diluted luciferase to oxidation of sulfhydryl groups, since addition of cysteine counteracts this inactivation. From our earlier experiments ${ }^{6}$ we concluded that inactivation of diluted enzyme is due to dissociation of some active group, called U, that may be "bound" to the enzyme via sulfhydryl groups. If the sulfhydryl groups then are oxidized after dissociation reassociation of the active group $\mathrm{U}$ may be prevented.

It is possible that $\mathrm{FMNH}_{2}$ reduces the active group $\mathrm{U}$, which in turn re-reduces the fluorescing group. A discrepancy between our experiments and those of Hastings AND GIBSON ${ }^{11}$ could be explained in terms of such a reaction. The latter authors found that luciferase oxidizes $\mathrm{FMNH}_{2}$. In our previous experiments ${ }^{12}$ we demonstrated that luciferase preparations contain an $\mathrm{FMNH}_{2}$-oxidizing substance which inhibits the light reaction. If the group $U$ is identical with this substance, it may be that in the experiments of HAstings AND GIBSON the group U was, for the greater part, bound to the luciferase, whereas, in our experiments, the solution surrounding the luciferase molecules contained considerable quantities of free U groups. It should be understood that $\mathrm{U}$ can act as an inhibitor only if the quantity of $\mathrm{FMNH}_{2}$ becomes limiting for the amount of luciferase present 
$\mathrm{FMNH}_{2}$ is essential for the light reaction. From previous experiments we concluded ${ }^{10}$ that $\mathrm{FMNH}_{2}$ is attached to the enzyme at two sites, probably the aldehyde and the fluorescing group. It is possible that the oxidation energies of the two substances, $\mathrm{FMNH}_{2}$ and the fluorescing group, are combined in the bioluminescence reaction. In Fig. 6 a hypothetical reaction scheme is shown that fits both our experiments and those of HASTINGS AND GIBSON. In this scheme Fl represents the fluorescing group at the luciferase molecule. As aldehyde, if indeed playing a role in the
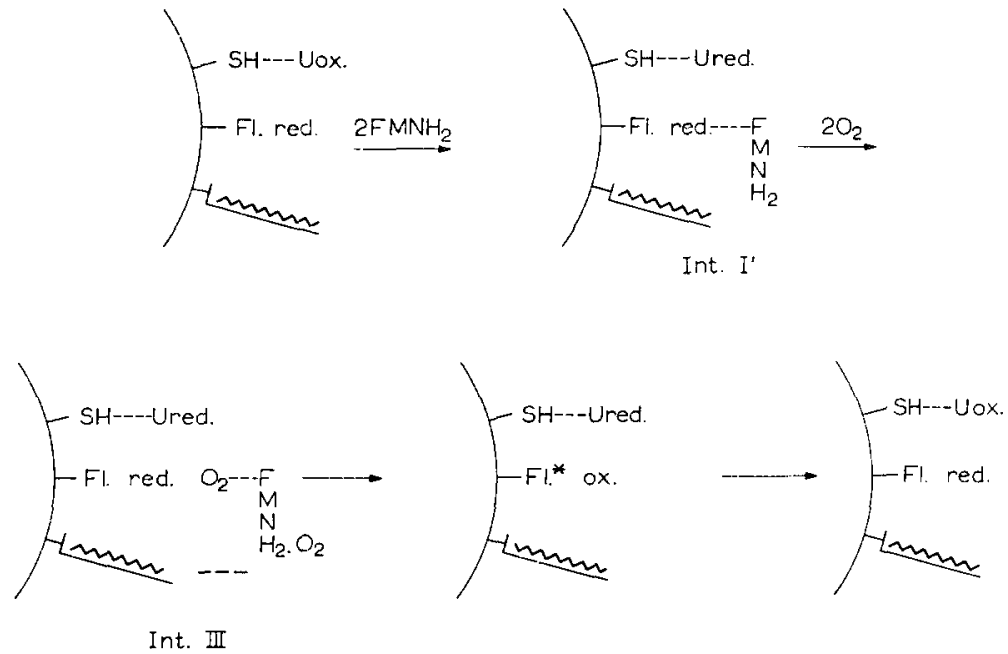

Int. III

Fig. 6. A hypothetical reaction scheme for bacterial bioluminescence. For explanation see text.

living cell, will probably be "permanently" attached to the enzyme10,13, the intermediates I and II of HASTINGS AND GIBSON ${ }^{11}$ will be replaced by a single intermediate $I^{\prime}$. It may be recalled that, from earlier results, we found no reason to assume that aldehyde is oxidized during the light reaction ${ }^{10}$. The most essential feature of the proposed scheme is that the light reaction consists of two reactions, namely an oxidation of the fluorescing group and a subsequent reduction by a reduced group of the enzyme.

Using this scheme we will try to explain the results of the experiments described above.

As the light reaction consists of two consecutive reactions, inhibition of one of these should inhibit the light reaction. The fluorescence increase effect, on the contrary, is assumed to be connected with oxidation of the fluorescing group on binding of $\mathrm{FMNH}_{2}$. This effect should not be inhibited, therefore, by agents interacting only with the group $\mathrm{U}$.

$\mathrm{K}_{4} \mathrm{Fe}(\mathrm{CN})_{6}$ inhibits the fluorescence increase effect. Therefore, it may in some way interfere with the fluorescing groups. At low $\mathrm{FMNH}_{2}$ concentration, $\mathrm{K}_{4} \mathrm{Fe}(\mathrm{CN})_{6}$ inhibits the light reaction, whereas increasing the $\mathrm{FMNH}_{2}$ concentration tends to cancel this inhibition. Probably, $\mathrm{K}_{4} \mathrm{Fe}(\mathrm{CN})_{6}$ and $\mathrm{FMNH}_{2}$ interact with the same site of the enzyme. As it was concluded that $\mathrm{K}_{4} \mathrm{Fe}(\mathrm{CN})_{6}$ may interfere with the fluorescing groups, the interaction is, probably, with these groups. It is possible that the $\left[\mathrm{Fe}(\mathrm{CN})_{6}\right]^{4-}$ ions screen the (positively charged) fluorescent groups at the enzyme. 
$\mathrm{K}_{4} \mathrm{Fe}(\mathrm{CN})_{6}$ shows a rather high inhibiting effect in the fluorescence increase reaction as compared to the inhibiting effect in the light reaction. This may be explained by assuming that $\mathrm{K}_{\mathbf{4}} \mathrm{Fe}(\mathrm{CN})_{6}$ inhibits the fluorescence effect in two ways; namely, directly by interaction with the fluorescing groups and indirectly by inhibiting the photooxidation of the compound formed on combination with $\mathrm{FMNH}_{2}$.

The inhibiting effect of $\mathrm{K}_{3} \mathrm{Fe}(\mathrm{CN})_{6}$ on both the fluorescence increase reaction and the light reaction is caused, probably, by its influencing the fluorescing groups and by oxidation of added $\mathrm{FMNH}_{2}$.

At relatively high $\mathrm{FMNH}_{2}$ concentration, $\mathrm{K}_{4} \mathrm{Fe}(\mathrm{CN})_{6}$ may have an activating effect on the light reaction. This effect does not show up in the presence of cysteine. The activation by $\mathrm{K}_{4} \mathrm{Fe}(\mathrm{CN})_{6}$ may be due, therefore, to preventing oxidation of sulfhydryl groups as a result of its reducing action. Another possibility may be that $\mathrm{K}_{4} \mathrm{Fe}(\mathrm{CN})_{6}$ has some, as yet unknown, effect on group $\mathrm{U}$.

At high enzyme concentrations the activating action of $\mathrm{K}_{4} \mathrm{Fe}(\mathrm{CN})_{6}$ becomes less conspicuous, presumably because a relatively small number of $\mathrm{U}$ groups is dissociated. Therefore, at high enzyme concentration the inhibiting action will, relatively, increase, as was found in the experiments.

Ascorbic acid inhibits the fluorescence effect, so it may be supposed to act, in some way, via the fluorescing groups. As the inhibiting effect in the light reaction is only slightly counteracted by high $\mathrm{FMNH}_{2}$ concentration, competition of ascorbic acid and $\mathrm{FMNH}_{2}$ is in favour of ascorbic acid. High enzyme concentrations result in less inhibition by ascorbic acid: relatively less fluorescing groups are occupied.

A protecting effect, if any, of ascorbic acid on sulfhydryl groups, as a result of its reducing action, apparently influences the light reaction to a much smaller degree than via the fluorescing groups. This is deduced from the finding that the inhibitory effect of ascorbic acid and oxidized ascorbic acid does not differ significantly.

The inhibitors of the light reaction discussed until now are assumed to act via the fluorescing group. An inhibitor acting via $U$ or sulfhydryl groups, such as e.g. $p$-chloromercuribenzoate, may be expected not to influence the fluorescence increase effect. This indeed proved to be the case.

Peroxidase inhibits the light reaction and does not influence the fluorescence increase effect. It does not seem likely, however, that peroxidase acts via the sulfhydryl or U groups. As peroxides are generally supposed to play a role in chemiluminescence ${ }^{14,15}$, peroxidase probably interferes with the light reaction after the binding of $\mathrm{FMNH}_{2}$ to the fluorescing groups (cf. Fig. 6).

Tryptophan may react with $\mathrm{FMNH}_{2}$ in the same way as the fluorescing group of luciferase, as it shows a similar fluorescence increase reaction ( $c f$. Fig. 3e). As it does not interfere with the fluorescing groups, it is understandable that no influence on the light reaction was measured. The finding that tryptophan and luciferase preparations show similar fluorescence increase effects may indicate that during the reaction of enzyme and $\mathrm{FMNH}_{2}$ a "charge-transfer complex" is formed, as is the case with tryptophan and FMN (refs. 7,8 ). As the reactions of tryptophan with $\mathrm{H}_{2} \mathrm{O}_{2}$ and FMN are not the same as those of the enzyme preparations, we tentatively conclude that the fluorescent groups are not identical with tryptophan. In this connection it may be of interest that CORMIER AND ECKROADE ${ }^{16}$ report that indole and many of its derivatives show a bluish-green luminescence (maximum at about $480 \mathrm{~m} \mu$ ) in dimethylsulfoxide in the presence of $\mathrm{H}_{2} \mathrm{O}_{2}$. 
In brief, the questions posed in the introduction may be answered as follows. The formation of the compound with a fluorescence maximum at about $470 \mathrm{~m} \mu$ in the fluorescence increase reaction is, probably, an oxidation, as judged from experiments with $\mathrm{H}_{2} \mathrm{O}_{2}$. If a substance inhibits the fluorescence increase effect by combining with the fluorescent group at the enzyme, it will inhibit the light reaction too.

\section{REFERENCES}

1 W. Terpstra, Biochim. Biophys. Acta, 75 (I963) 355.

2 L. R. Tether and J. H. Turnbull, Biochem. J., 85 (I962) $5 \mathrm{I} 7$.

${ }^{3}$ M. J. Cormier, J. R. Totter and H. H. Rostorfer, Arch. Biochem. Biophys., 63 (1956) $4^{\mathrm{I}} 4$.

4 W. D. McElroy and A. A. Green, Arch. Biochem. Biophys., 56 (1955) 240.

5 W. H. Riley, Thesis, University of Illinois, I 962.

${ }_{6}$ W. Terpstra, Biochim. Biophys. Acta, 60 (1962) 580.

7 I. Isenberg and A. Szent-Györgyi, Proc. Natl. Acad. Sci. U.S, 45 (I959) I 22.

8 I. Isenberg, A. Szent-Györgyi and S. L. Baird, Jr., Proc. Natl. Acad. Sci. U.S., 46 (I 960 ) I 307.

9 B. L. Strehler and M. J. Cormier, Arch. Biochem. Biophys., 47 (I953) I6.

${ }_{10}$ W. Terpstra, Biochim. Biophys. Acta, 4 I (1960) 55.

$11 \mathrm{~J}$. W. Hastings and Q. H. Gibson, J. Biol. Chem., 238 (I963) 2537.

12 W. Terpstra and H. G. Van EiJk, Biochim. Biophys. Acta, 5 I (I96I) 473.

13 W. Terpstra, Biochim. Biophys. Acta, 28 (I958) I 59.

14 H. Linschitz, in W. D. McElroy And B. Glass, Light and Life, The Johns Hopkins Press, Baltimore, I961, p. I 73 .

15 E. H. White, in W. D. McElroy and B. Glass, Light and Life, The Johns Hopkins Press, Baltimore, I $96 \mathrm{I}$, p. I 83 .

16 M. J. Cormier aNd C. B. Eckroade, Biochim. Biophys. Acta, 64 (1962) 340. 